\title{
DE DE GRUYTER \\ OPEN \\ The need for digital and soft skills in the Romanian business service industry
}

\author{
Ulrike Stefanie FOERSTER-PASTOR (FOERSTER-METZ) \\ The Bucharest University of Economic Studies, Bucharest, Romania \\ Ulrike.s.foerster@web.de \\ Nina GOLOWKO \\ The Bucharest University of Economic Studies, Bucharest, Romania
}

\begin{abstract}
The Romanian Business Service Sector developed fast in the last decade. Today it employs more than 120000 Head Counts and continuously grows. However, companies claim not to get the right skills from employees to pursue the digital transformation from a mere service sector towards a more value-added service. Since it has a very young working population with an average age between 26 and 35 years, it is increasingly important to review the employability skills needed by this industry to safeguard the continuation of the sector. So far, Romanian studies have been deducted reflecting the skills needed from the sector. In the first instance, these studies used the questionnaire methodology or global surveys mostly on a very holistic view (ABSL, 2017; Boșcor and Băltescu, 2014). This paper shows a new approach by deriving the skills needed by employers from their own database: job descriptions of entry positions published in companies or job boards were analyzed within a specified period, allowing an accelerated approach to defining skills needed without a too high time delay given the rapid progressing digitalization. The job descriptions are analyzed by using the method of qualitative content analysis according to Mayring (2014) using specific criteria based on the literature review of employability skills. Key findings confirm demand for hard skills such as languages and IT skills such as Office Suits, Development Environments as well as higher demand for soft skills especially analysis and problem solving induced by digitalization.
\end{abstract}

Keywords: employability, soft skills, digital, outsourcing, Romania.

Please cite the article as follows: Foerster-Pastor, U.S., and Golowko, N. (2018), "The need for digital and soft skills in the Romanian business service industry", Management \& Marketing. Challenges for the Knowledge Society, Vol. 13, No. 1, pp. 831-847, DOI: 10.2478/mmcks-2018-0008.

\section{Introduction}

Romania's Business Service Sector (BSS) - also referred to as Outsourcing in generic terms - continues to be an attractive and growing nearshore location for West European countries. Generally speaking, outsourcing refers to a subset of services that are relocated to third parties outside a company, and that was traditionally performed in-house by the company's human resources. Thus, it can affect jobs ranging from customer support to manufacturing to the back office and is usually done as a measure of cost reduction (Investopedia, 2017a).

The latest A.T Kearney Global Location Index Report (2016) shows that Romania moved up the ladder by 5 points to place number 13, following Poland (10), Vietnam (11) and Bulgaria (12). Considering the employment rate, the primary activity within this outsourcing sector in Romania pertains to the subsectors Business Process Outsourcing (BPO) with 33\% and IT-Outsourcing (ITO) with 34\%. The relatively new subsector Shared Service Center (SSC) which refers to the consolidation and centralization of service 
processes within an organization follows with 25\%. Research and Development account $8 \%$, which is relatively narrow due to the highly-sophisticated skill requirements (CBRE, 2015). The ITO, BPO and SSC sector in Romania was the second biggest contributor to GDP growth after consumption, even though it only accounts for $12 \%$ of the GDP (Colliers International, 2017). According to the latest ABSL report, it will continue to grow its current workforce population of 120.000 headcounts by 14\% in 2018 (ABSL, 2017).

At the same time, this sector as any other industry considers productivity gains by continuously automating activities driving the digitalization process. In Romania, there are many driving forces for this: a shrinking workforce population due to demographic decline as well as migration towards other countries. It is estimated that three million Romanians have decided to move abroad after 1990 out of which $46 \%$ are aged 20-34 (Marius et al., 2017). Therefore, this results in a lack of talent across different industries in Romania which consequently increases the competition to attract, retain and grow talent. Moreover, it induces salaries growth, affecting the workforce population of the Business Services Industry whose average age is 26 to 35 years old (ABSL, 2017).

Furthermore, the latest Deloitte Global Shared Services Report (2017) shows that finding the "right" talent - that can cope with the increasingly diverse skill set required by regional and global process owners in the industry as an outcome of continuously driving end-to-end efficiency and effectiveness - increasingly challenges this specific sector. According to Lacity and Willocks (2016), the traditional business outsourcing industry in which companies buy service automation as part of a group of integrated services has developed notable automation capabilities. Repeatable tasks free up employees to do for example more customer-facing activities. Thus, the industry needs to rethink the talent development and skills needed for an enterprise automation capability. If robots are doing the repetitive tasks, humans will gain more potential for creativity, problem-solving, judgment and emotional intelligence to solve unpredictable and unstructured issues (Lacity and Willocks, 2016).

The increased automation and digitalization of work raises the concern how governmental institutions, the educational system and the business outsourcing sector can comply with the human capital in demand. For this purpose, it is essential to understand the concept of employability skills as these skills are to a certain extent dictated by the employer. This paper is based on previous findings by the authors on employability skills for the Romanian Outsourcing Industry (Foerster-Pastor and Golowko, 2017). This paper extends this previous research following two new objectives. First: which specific IT skills are requested by the analyzed industry? Second: could it be that specific job categories within the industry demand for a different skills set?

The article is structured as follows. First, the authors provide an in-depth literature review on the concept of employability and employability skills. A summary of their precedent research presented in the ICBE conference 2017 on the employability skills for the Romanian Outsourcing Industry follows to acquaint the reader with the anterior research findings which raised new research objectives based on the research results. After that, the subject of study is described followed by the methodology and the results. Finally, the authors provide their conclusions on the findings. The research is not limited to a subsector of the Outsourcing Industry in Romania because the jobs descriptions analyzed do not allow a specific distinction between the subsectors. Also, the authors have made a 
review of the skills most demanded across each job categories considering that a baseline qualification is such that is requested irrespective of a specific job category.

\section{Literature review}

\section{Employability}

According to Dearing (1997) employability means merely the "acquisition of skills for life". This early definition has been expanded and detailed throughout the last two decades. By now a multitude of definitions can be found in scientific literature considering different perspectives, see following Figure 1.

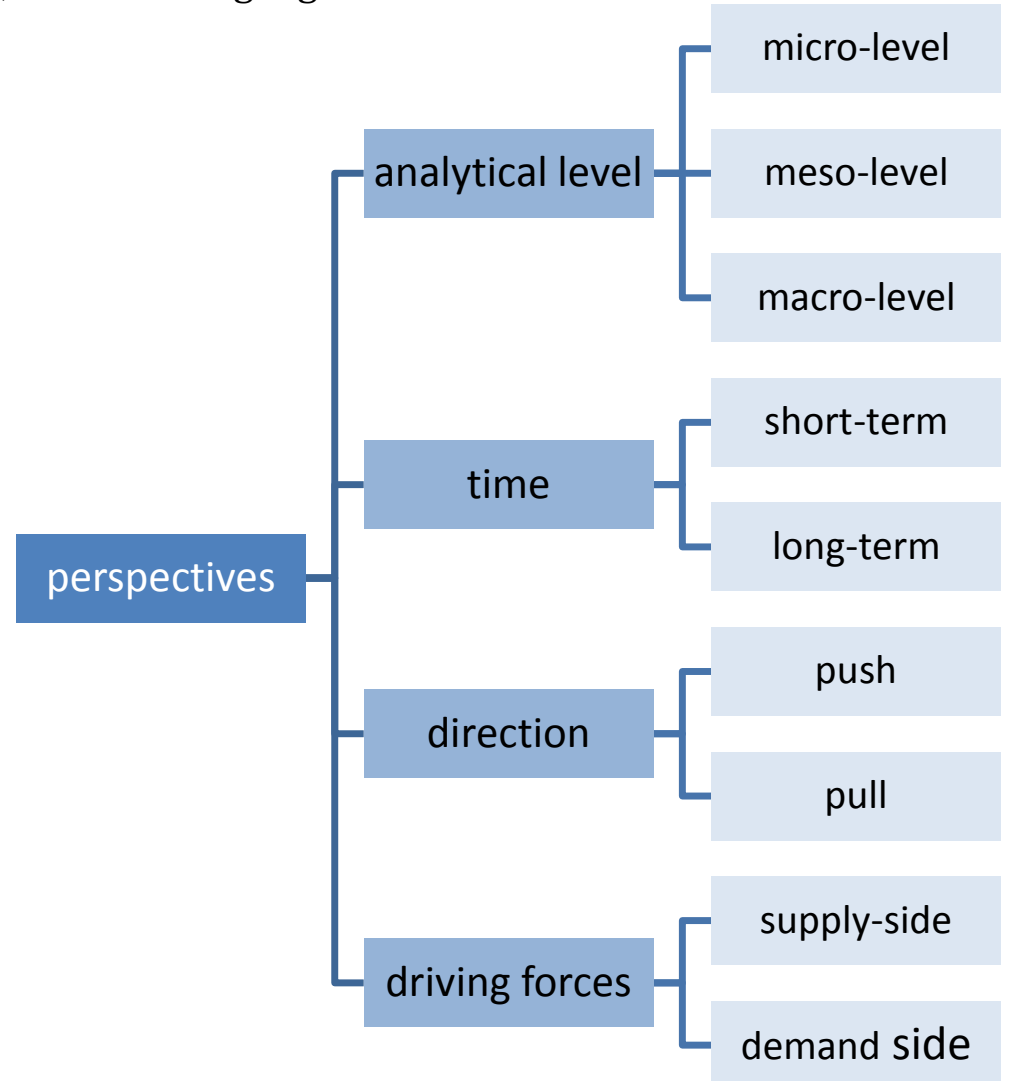

Figure 1. Perspectives of employability

Source: Authors' own compilation.

\section{Analytical level}

In general in sociology, three analysis levels are frequently proposed due to the scale. The micro-level reflects upon the individual or individual actors, the meso-level upon organizations and cooperative actors, and the macro-level comprises the whole of society (Blalock, 1979; Preisendörfer, 2015).

The possession of all necessary skills for or in the specific employment of an individual represents the micro-level of employability (Dearing, 1997). These skills can either be acquired during the education process in school and higher education institutions before entering the labor market (often referred to as work readiness) or through continuing professional development programs during all working phases (Gerholz and Sloane, 2011). Institutional or even regulatory approaches supplement this approach of 
personal achievement (Oria, 2012). Companies increasingly must secure skilled employees due to changes in technology, work processes, global institutional transformations and demography (PwC, 2014).

Society's view on which skills are necessary for a global context represents the macro-level (ESECT, 2017). The level of skills and competencies of employees are even interpreted regarding the overall prosperity of nations (EC, 2010; European Commission, 2014).

\section{Time}

The typical phases of the employment relationship are not only to gain initial employment, but to integrate into the processes, to be able to add value to the company (and society), and finally to remain employed, even in various employments (Kraus, 2007; Ismail and Mohammed, 2015). The focus, therefore, can lie on an individual's ability to become attractive for a specific employer (Oria, 2012) to find initial employment. The education system should provide these necessary skills.

As nowadays initial employment is not obtained the whole work life through and the labor markets are subject to rapid changes and requirements, it is crucial to be able to handle all transitions during the whole professional life. So, a person's skills must be developed throughout the whole work life, too (Hillage and Pollard, 1998).

\section{Direction}

Closely linked to the time perspective is the question whether skills are pushed into the market by the future employees or pulled by the companies. Either the companies have to deal with the results of the education system and must filter out the best matching applicants, or by explicitly demanding for specific key skills the companies can set standards the education system must follow, concerning, for example, the usage of new technology.

This question is widely discussed, especially as several authors state that more or less significant gaps between the skills searched for by the companies and provided by the employees can be observed in capitalist economies due to globalization and technological innovations (Barrett et al., 2005; Belfiore et al., 2004). Asonitou (2015, p. 285) comprises research conducted in different professions in her article which shows that "the pace of technology and global business expansion is not moving in parallel to the pace of professionals' skills improvement."

The scope of employability skills nowadays asked for ranges from skills in the specific field of work, i.e., technical, economic or IT skills, to soft skills, i.e., personal, social and communication skills, resilience, flexibility, empathy, integrity or ethical conduct. Some authors even identified soft skills as more important than hard skills (Asonitou, 2015). Thus, the question arises whether an education system - in the first place providing hard skills - would build such competencies and soft skills.

\section{Driving forces}

Analogous to other markets, skills are demanded and supplied, too. The expectations of the labor market in general or a specific employer represent the demand-side of employability. Either the employee himself or a school or higher education institution that provides knowledge and skills to the future employee represents the supply-side (Golowko et al., 
2017). Research in the fields of e. g. didactics or curriculum development deals with the skills that should be supplied by higher education to meet the future needs of the market (Niethammer et al., 2014). Supply and demand are thus closely linked. The German Scientific Council, for instance, asks for employability based on science which is determined by the labor market's expectations (Wissenschaftsrat, 2000).

In the context of a globalized society, an individual competes with high-performers all over the world. The importance of employability skills thus steadily grows - but also becomes increasingly complex (Oria, 2012).

\section{Employability skills}

A skill is the ability to do something well. Expressions like expertise, competence, capability, experience, professionalism or talent are often taken as synonyms. It can also be used meaning a particular ability like a specific gift or strength (Oxford Dictionary, 2017). Harvey et al. (2002) explained employability skills as the "willingness to learn and be employed". To specify this first very general approach, there is a multitude of definitions and classifications of employability skills in the literature. The following Table 1 provides an overview of often cited approaches in this field.

Table 1. Overview of definitions and classifications of employability skills in the literature

\begin{tabular}{|c|c|c|}
\hline Author(s) and year & Definition of employability & $\begin{array}{l}\text { Model/Categories/ } \\
\text { Characteristics }\end{array}$ \\
\hline Hillage and Pollard (1998) & $\begin{array}{l}\text { The "capability to move self- } \\
\text { sufficiently within the labor market to } \\
\text { realize potential through sustainable } \\
\text { employment". }\end{array}$ & $\begin{array}{l}\text { - employability assets } \\
\text { - deployment skills } \\
\text { - presentation skills } \\
\text { - personal circumstances }\end{array}$ \\
\hline Knight and Yorke (2003) & $\begin{array}{l}\text { A set of skills that "make an individual } \\
\text { more likely to secure and be successful } \\
\text { in their chosen occupation(s) to the } \\
\text { benefit of themselves, the workforce, } \\
\text { the community and the economy". }\end{array}$ & $\begin{array}{l}\text { USEM model (used in curriculum } \\
\text { development) } \\
\text { - } 4 \text { Components (understanding, } \\
\text { beliefs, meta-cognition, efficacy) } \\
\text { - } 39 \text { dimensions of skills }\end{array}$ \\
\hline Archer (2005) & $\begin{array}{l}\text { Description of required vital qualities } \\
\text { from the employer's perspective. }\end{array}$ & $\begin{array}{l}\text { - Intellectual ability } \\
\text { - Languages } \\
\text { - business awareness } \\
\text { - performance } \\
\text { - empowerment } \\
\text { - international outlook }\end{array}$ \\
\hline Shiel et al. (2005) & $\begin{array}{l}\text { The ability to cope with a globalized } \\
\text { and complex world and to } \\
\text { "understand the issues of sustainable } \\
\text { development". }\end{array}$ & $\begin{array}{l}\text { - self-reliant } \\
\text { - connected } \\
\text { - well-rounded } \\
\text { - critical } \\
\text { - a specialist in the respective field } \\
\end{array}$ \\
\hline $\begin{array}{l}\text { Andrews and Higson } \\
(2008)\end{array}$ & $\begin{array}{l}\text { "... key individual- and business- } \\
\text { related skills and competencies } \\
\text { required by employers of business } \\
\text { graduates and holders of other higher } \\
\text { level qualifications". }\end{array}$ & $\begin{array}{l}\text { - Hard skills (business-related } \\
\text { knowledge) } \\
\text { - Soft skills (interpersonal } \\
\text { competencies, work experience, } \\
\text { and work-based learning) }\end{array}$ \\
\hline Bridgstock (2009) & $\begin{array}{l}\text { "...desirable graduate attributes that } \\
\text { acknowledges the importance of self- } \\
\text { management and career building skills } \\
\text { to lifelong career management and }\end{array}$ & $\begin{array}{l}\text { Conceptual model of graduate } \\
\text { attributes for employability } \\
\text { including career management skills } \\
\text { - Self-management skills } \\
\end{array}$ \\
\hline
\end{tabular}




\begin{tabular}{|l|l|l|}
\hline & enhanced employability". & $\begin{array}{l}\bullet \text { Career building skills } \\
\text { - Discipline specific skills } \\
\bullet \text { Generic skills } \\
\bullet \text { Underpinning traits and } \\
\text { dispositions }\end{array}$ \\
\hline $\begin{array}{l}\text { Ismail and Mohammed } \\
(2015)\end{array}$ & $\begin{array}{l}\text { A "set of skills, knowledge and } \\
\text { attributes that likely make individual } \\
\text { to gain, maintain and excel in } \\
\text { employment; obtain new employment; } \\
\text { move between roles within the same } \\
\text { organization and to get } \\
\text { Promotion". }\end{array}$ & $\begin{array}{l}\text { Core skills (defined as the } \\
\text { technical competencies to } \\
\text { efficiently use equipment and } \\
\text { tools) }\end{array}$ \\
$\begin{array}{l}\text { generic skills (non-technical } \\
\text { competencies (e. g. social skills)) } \\
\text { personal attributes (the } \\
\text { individual's attitudes and traits) }\end{array}$ \\
\hline
\end{tabular}

Source: Authors' own compilation based on Foerster-Pastor and Golowko (2017).

The definitions and categories mentioned above can further be divided into different points of views: employability skills either generally regarding an individual, graduate employability provided by higher education institutions or skills demanded by the employers.

In this context Stiwne and Alves (2010) state that employers preferred personal attributes and skills to an academic career when the amount of graduates rises. Hence employers focus on employability as a person's behavioral competence and capacities. The traditional academic, theoretical knowledge is often considered as less important. Work experience and economic understanding are equally highly ranked as selection criteria. Consequently, companies search for graduates with short learning curves, thus ensuring a fast-vocational adjustment, important in increasing markets and under competitive pressure (Stiwne and Alves, 2010).

As Foerster-Pastor and Golowko (2017) state, "though the terms, the wording, the amount and the perspectives differ, all these specifications of employability skills have one aspect in common. They distinguish between intangible aptitudes related to the specific individual and tangible skills". These tangible skills can be measured in the form of academic achievement and degrees, as they are the outcome of education and further training (Knight and Yorke, 2004; Pietro and Cutillo, 2006; Andrews and Higson, 2008).

\section{Employability Skills in the Romanian Outsourcing Industry}

Human Capital is becoming more important as the international economy becomes more digitalized and services oriented. Regarding the hard and soft skills needed by the outsourcing industry, the Romanian academic literature remains understudied so far especially concerning the soft skills needed. Most studies relate to investments in IT and language skills (ABSL, 2017; Boşcor and Băltescu, 2014).

Therefore, the authors' initial study approach was to understand the skill set demand of the industry, by analyzing the existing state of literature concerning employability skills in general as well as focussing on the outsourcing industry. FoersterPastor and Golowko (2017) identified a set of hard, soft and personal attributes derived from

- factors affecting location competitiveness,

- the business services provided, 
- the literature related to the future trends in the workforce due to the digitalization of things,

- the demands of different associations belonging to the outsourcing industry in the world and Romania.

Table 2 shows the identified skills per category.

Table 2. Skills categories analyzed

\begin{tabular}{|l|l|l|}
\hline Hard Skills & Soft Skills & Personal Attributes \\
\hline Languages & Analysis and Problem Solving & Learning \\
\hline IT & Communication & Flexibility \\
\hline Data Entry / Data Analysis & Team Work & Enthusiastic \& Positive \\
\hline Accounting / Finance & Customer Service Orientation & Resilience \\
\hline Project Management & Proactivity / Business Acumen & Results oriented \\
\hline Process Management & Attentiveness & Innovation \\
\hline Sales Knowledge & Autonomous work & Ethical skills \\
\hline Teaching & Time Control / Prioritization & Empathy \\
\hline Human Resources & Multitasking & \\
\hline Warranty knowledge & Organizational skills & \\
\hline Procurement Knowledge & Cultural Awareness & \\
\hline
\end{tabular}

Source: Foerster-Pastor and Golowko, 2017.

After that, they investigated if the identified employability skills reflected in the qualification requirement of a set of 91 job descriptions of the Romanian Outsourcing Industry. They concluded on their research that the following skills were most demanded.

Regarding hard skills, soft skill and personal attributes the most requested by the analyzed industry were by far IT and languages skills followed by analysis and problem solving, communication, teamwork as well as a learning attitude, flexibility and a positive and enthusiastic spirit. Less demanded were on the hard skill side specific knowledge of the job description function. Regarding employee-centric soft skills attentiveness, autonomous work, time control and ability to prioritize were fewer mentioned. A detailed overview of the study's results shows Table 3.

Table 3. Summary of key results by Skill Category

\begin{tabular}{|c|c|c|c|c|}
\hline Empl & \multicolumn{4}{|c|}{ Romanian BPO Industry } \\
\hline Skill Category & Hard & & & Personal Attribute \\
\hline Relation & & $\begin{array}{l}\text { Customer } \\
\text { Centric }\end{array}$ & Employee Centric & \\
\hline Specific Skill & $\begin{array}{ll}+ & \text { IT } \\
+ & \text { Languages } \\
\circ & \text { Data } \\
& \text { analysis } \\
& \text { Project \& } \\
& \text { process } \\
& \text { manageme } \\
& \text { nt } \\
- & \text { Specific } \\
& \text { outsource }\end{array}$ & $\begin{array}{ll}+ & \begin{array}{l}\text { Analysis \& } \\
\text { problem }\end{array} \\
& \text { solving } \\
+ & \text { Communicati } \\
& \text { on } \\
+ & \text { Teamwork } \\
+ & \text { Customer } \\
& \text { service } \\
& \text { orientation } \\
- & \text { Cultural }\end{array}$ & $\begin{array}{ll}- & \text { Attentiveness } \\
- & \text { Autonomous } \\
& \text { work } \\
- & \text { Time control } \\
& \text { \& ability to } \\
& \text { prioritize } \\
- & \text { Multitasking } \\
& \text { organizational } \\
& \text { skills }\end{array}$ & $\begin{array}{ll}+ & \text { Learning } \\
& \text { Attitude } \\
+ & \text { Flexibility } \\
+ & \text { Positive } \\
& \text { Enthusiastic } \\
\circ & \text { Resilient } \\
\circ & \text { Results } \\
& \text { oriented } \\
- & \text { Creativity } \\
- & \text { Empathy }\end{array}$ \\
\hline
\end{tabular}




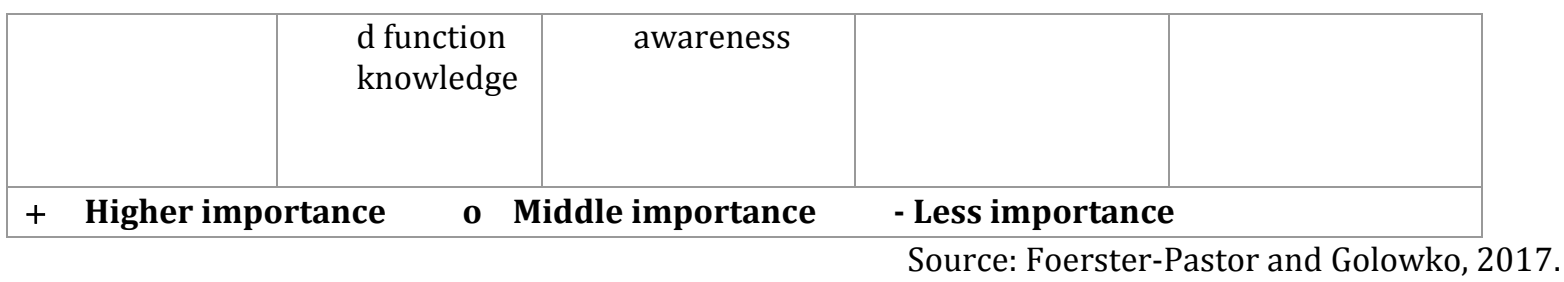

Due to the high request of IT skills by the studied industry and the lack of further specification of the IT skills in the precedent research of the authors, there is the need to extend the research by a new objective namely understanding which are the specific digital skills needed. Furthermore, the initial research outcome did not provide information if there was a typical distribution of skills across job categories as it only gave a general demand across all job categories. This raised the question if there might be some job categories that do not follow the above trend of the most demanded skills.

\section{IT Skills}

Based on the current discussion on the demand of digital skills needed in the outsourcing industry in Romania as well as the high importance that is given to these skills within the industry on an international level, it is essential to understand which type of digital knowledge is requested by the industry as a specific hard skill whilst taking a more detailed approach. In countries like the Philippines and India, the BPO industry has already taken measures to support the growth of digital skills. These are digital marketing including social media management, application development, and maintenance, enterprise resource planning (ERP) systems knowledge for SAP and Oracle, Java emerging technologies such as Cloud and specific language skills such as JAVA (Patag, 2017; Basavarage and Anjaneya, 2014).

Further based on an analysis done by Computerworld Forecast 2016 the following information technology skills have been identified as necessary for the technology services industry and are summarized in Table 4. The mention of the identified skills is limited by the survey to only those which are exclusively related to technical skills, as IT architecture for cloud computing as well as for enterprise architecture. Companies search for programming application development due to the continued increase of applications and the continuity of the internet of things. Web development environments knowledge is still of high importance as it developed as the primary channel to connect with customers, clients, partners and employees through the last two decades (Pratt, 2015). Furthermore, the outsourcing industry is marked by the standardizations of processed and the delivery of these through service desks. Therefore, it is crucial to know the field of Service Desk Management.

Table 4. IT Skill categories analyzed

\begin{tabular}{|l|l|}
\hline IT Skill Category & Definition and Examples \\
\hline Application Suites & $\begin{array}{l}\text { Group of programs that are sold as a package to solve common } \\
\text { problems. Also known as "productivity suites," they are "a set } \\
\text { of basic business programs designed with a uniform user } \\
\text { interface and common functions such as spell checking." The } \\
\text { primary programs are word processing, spreadsheet, and } \\
\text { presentation graphics. Examples: Microsoft Office, iWork, } \\
\text { WordPerfect Office, Lotus SmartSuite, StarOffice, Apache } \\
\text { OpenOffice, G Suite, Zoho and graphics suite. (Yourdictionary, } \\
2017)\end{array}$ \\
\hline
\end{tabular}




\begin{tabular}{|c|c|}
\hline Development Environments & $\begin{array}{l}\text { Environment referred as the compilation of hardware and } \\
\text { software tools specifically designed to aid in the development } \\
\text { of software and interfaces (Collins English Dictionary, 2014) }\end{array}$ \\
\hline Social Media & $\begin{array}{l}\text { Kaplan and Haenlein (2010, p. 61) define social media as "a } \\
\text { group of Internet-based applications that build on the } \\
\text { ideological and technological foundations of Web } 2.0 \text {, and that } \\
\text { allow the creation and exchange of user-generated content." }\end{array}$ \\
\hline Service Desk Management & $\begin{array}{l}\text { Service desks are systems designed to support the provision of } \\
\text { IT products and services. When experts refer to a service desk, } \\
\text { they refer to a support service that has specific capabilities } \\
\text { related to troubleshooting or calibrating products or services } \\
\text { (Technopedia, 2017a) }\end{array}$ \\
\hline Operating Systems & $\begin{array}{l}\text { A program that manages a computer's resources, especially } \\
\text { the allocation of those resources among other programs. } \\
\text { Typical resources include the central processing unit (CPU), } \\
\text { computer memory, file storage, input/output (I/O) devices, } \\
\text { and network connections. Examples: Windows, Linux. } \\
\text { (Britannica, 2017) }\end{array}$ \\
\hline Programming Language & $\begin{array}{l}\text { A programming language is "a computer language engineered } \\
\text { to create a standard form of commands. These commands can } \\
\text { be interpreted into a code understood by a machine. Programs } \\
\text { are created through programming languages to control the } \\
\text { behavior and output of a machine through accurate } \\
\text { algorithms, like the human communication process." } \\
\text { Examples: Java, C++, Cobol, Fortran (Technopedia, 2017b) }\end{array}$ \\
\hline Enterprise Resource Planning Systems & $\begin{array}{l}\text { Enterprise resource planning (ERP) is "a process by which a } \\
\text { company (often a manufacturer) manages and integrates the } \\
\text { important parts of its business. An ERP management } \\
\text { information system integrates areas such as planning, } \\
\text { purchasing, inventory, sales, marketing, finance and human } \\
\text { resources. ERP is most frequently used in the context of } \\
\text { software." Examples: NetSuite ERP, Oracle E-Business Suite, } \\
\text { SAP ERP, Sage 100c, PeopleSoft, Epicor ERP, SAP S/4HANA, } \\
\text { and Oracle ERP Cloud (Investopedia, 2017b) }\end{array}$ \\
\hline Network protocols & $\begin{array}{l}\text { Network protocols are "formal standards and policies } \\
\text { comprised of rules, procedures and formats that define } \\
\text { communication between two or more devices over a } \\
\text { network." Network protocols govern the end-to-end processes } \\
\text { of timely, secure and managed data or network } \\
\text { communication. Examples: communication protocols, such as } \\
\text { TCP/IP and HTTP Network security protocols: Implement } \\
\text { security over network communications and include HTTPS, } \\
\text { SSL and SFTP (Technopedia, 2017c) }\end{array}$ \\
\hline
\end{tabular}

Source: Authors' own research results.

\section{Methodology, data analysis, and results Methodology}

This research follows the methodology used by Bennett (2002) who made a content analysis of transferable skills demanded by employers in the UK. It is slightly modified by limiting it to a sector and by extending it to some hard skills, leaving out an additional questionnaire to managers. Furthermore, the authors also recognize the methodology of Burning Glass Technologies (2015) who make an extensive analysis of job descriptions in the USA by skills' importance in an occupation, and how frequently that occupation's job postings request a skill. In this way baseline skills are defined for job categories. 
Two questions have been addressed based on previous study outcome: "which are the IT-specific skills needed by the Romanian BPO industry?" and "is there a distinct or common distribution of employability skills demanded by job category?".

Regarding the first question corresponding to the digital skills requested by the industry, the defined set of job advertisements of the Romanian Outsourcing Industry was coded according to the deducted IT skills in the previous chapter. It is worth mentioning that analytical skills have been included in the initial research which in many cases also involves knowledge of specific software knowledge, but have been left out of the analysis presented here. Concerning the second objective, a cross job description analysis was deduced on the basis of the research results of Foerster-Pastor and Golowko (2017).

As scientific method, the qualitative content analysis by Mayring (2014) is used. His approach is a systematic, rule-governed text analysis of bigger text-corpora. Based on the quantitative content analysis, the methodology is enhanced qualitatively by embedding the material in its communication context.

\section{Data sample}

The authors make use of the same set of 91 job advertisements of 10 international outsourcing companies with a subsidiary in Romania as in their previous research to ensure consistency while extending their research (Foerster-Pastor and Golowko, 2017). These job advertisements were published on independent job boards as well as on the companies' career sites from November to December of 2016 and January of 2017. They were restricted to the following outsourced services which according to the ABSL Outsourcing Industry Report 2016 are the most outsourced services (in descending order): IT Services, Customer Operations, Finance \& Accounting, Human Resources, Procurement. The sample structure is displayed in Figure 2.

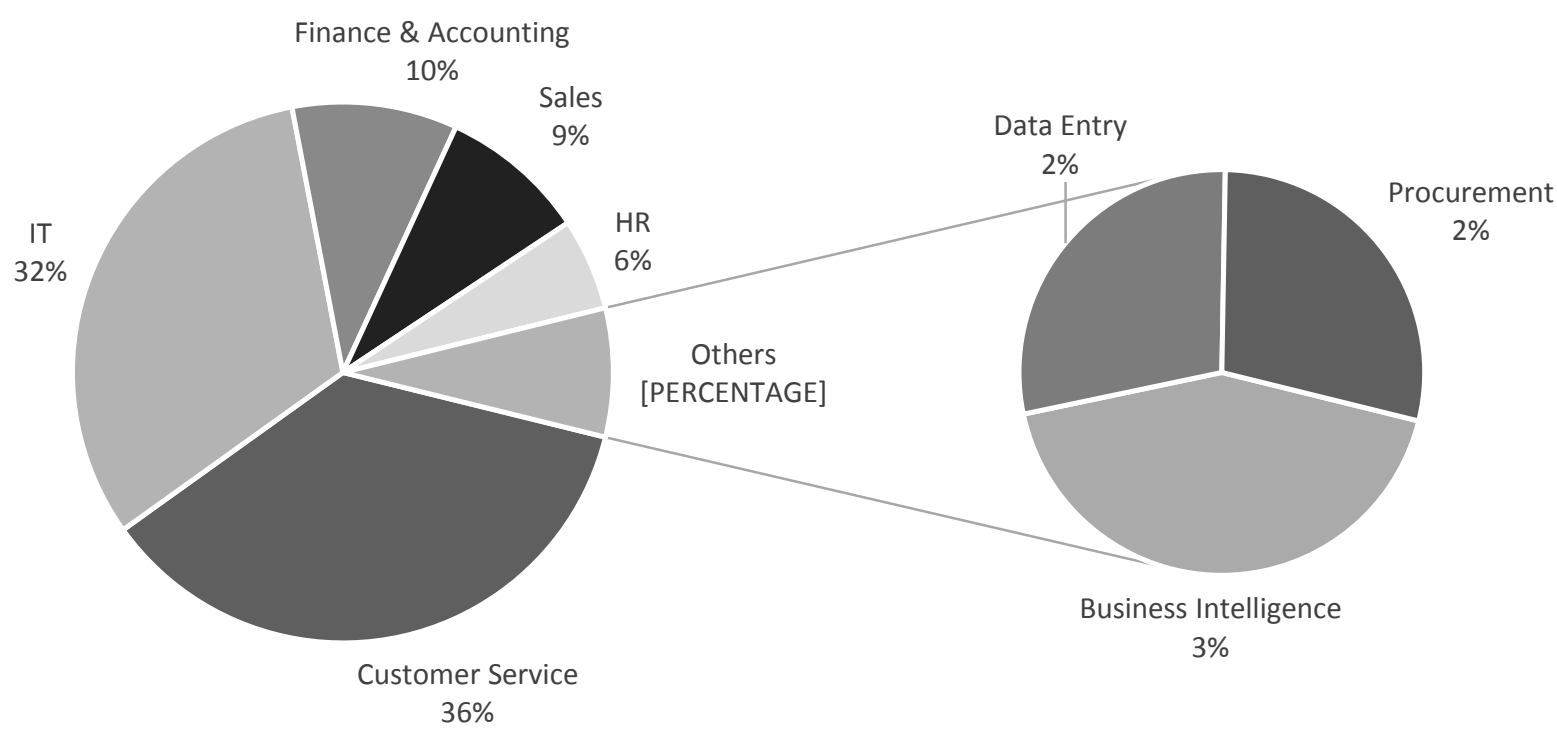

Figure 2. Sample structure of job advertisements surveyed by service sector

Source: Authors' own research results/contribution. 
The work location of the advertisements was restricted to the city of Bucharest since approx. $55 \%$ of the Business Outsourcing Industry in Romania is situated in this location (Marks, 2015). The job advertisements were limited to graduate or entry positions, meaning not demanding more than one year of professional work experience. Seasonal variations were not excluded therefore it rather seems a coincidence that the sample structure reflects in a way the relevance of the outsourced service sector.

However, this survey intends to give an initial direction on the skill requirements of the industry. Also, job descriptions which did not specifically mention years of required experience were double reviewed based on the professional experience and responsibilities demanded. In the understanding that senior-level positions require more complex strategic responsibilities as well as team leadership, job descriptions fulfilling these criteria were excluded from the studied sample.

The skill survey was limited to the specific qualifications often described in the section of a job description as qualifications and professional experience required. The section "main responsibilities indicated within the job advertisements" have been left out of the analysis as it left room for subjectivity but could be analyzed in future research.

\section{Results analysis}

The results show that from 91 job advertisements analyzed 75\% demanded IT skills. The level of digital literacy requested varied from medium to expert knowledge. The demand for higher literacy level despite entry-level positions can be explained due to the high percentage job descriptions dedicated to IT services which could be addressed to students coming from the IT and Science field who are expected to have this high degree of literacy. Figure 3. shows the number of mentions by digital skill category. It is worth mentioning that out of 91 analyzed job descriptions 89 did mention at least one of the analyzed IT skill categories.

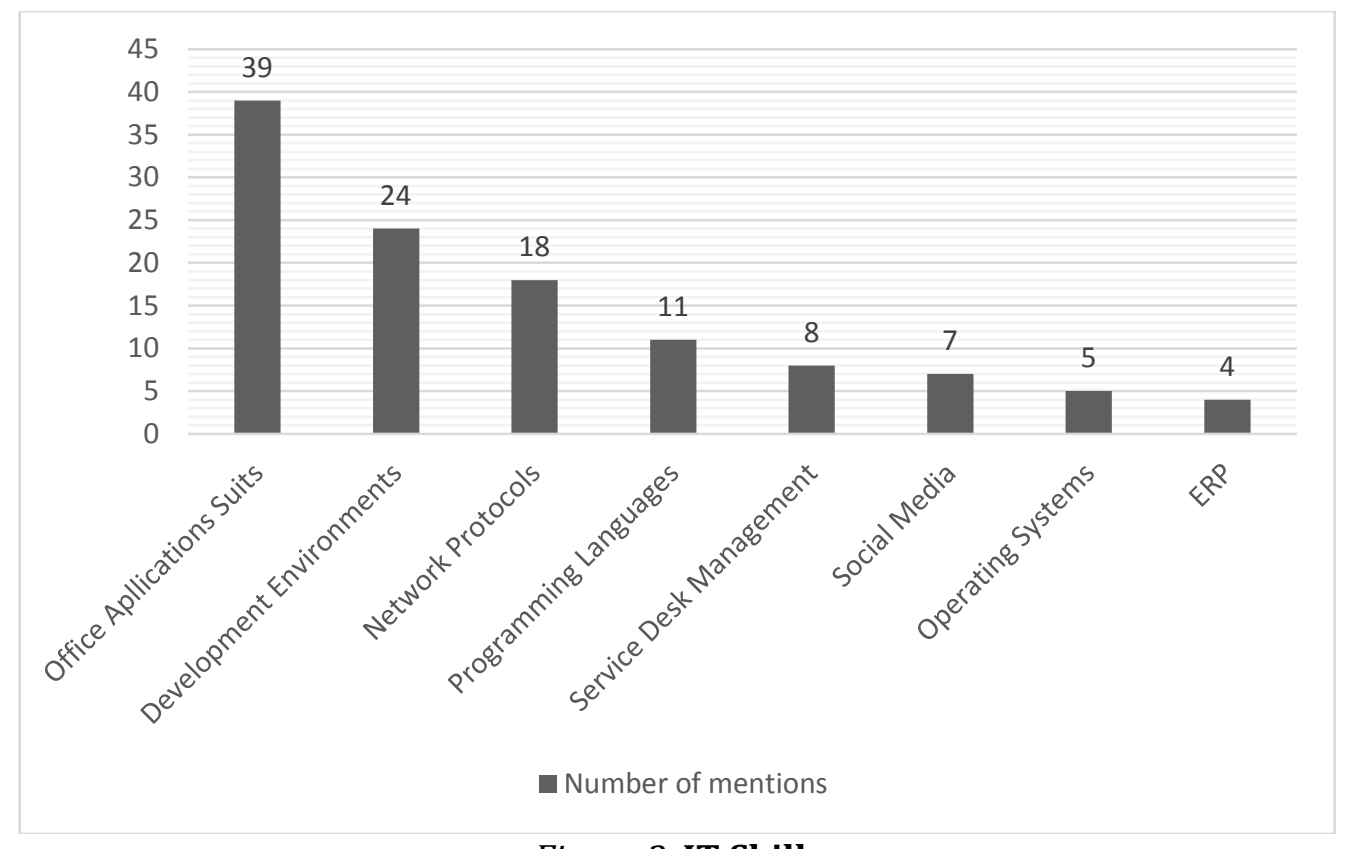

Figure 3. IT Skills

Source: Authors' own research results. 
The highest demand for IT skills required is office suits literacy, which is not surprising as this still is the primary communication channel dictated by the professional work environment. The incremental importance of working within software development environments shows the growing need to bring this topic closer to a broader population of future talent, what may be explained by the increased automation within the BPO industry. However, it seems that the need for knowledge of ERP is less which is an unexpected result. This topic will need further investigation, as ERP is most commonly used in the context of software (Investopedia, 2017b).

\section{Required skills across job categories}

To understand if specific skills are required across job categories the authors analyzed the percentage of skill demand per job category limiting the analysis to the following job categories Customer Service, IT, Finance, Sales and HR as these are the job categories with the highest number of job descriptions available within the data analyzed. In this way, six skills in common were identified across all analyzed job categories which are language, analysis, and problem-solving, IT, communication, teamwork, proactivity and business acumen. Skills with the highest number of percentage of skill mentions across all job categories are in descending order language, analysis and problems solving and IT. Figure 4 shows a summary of the results.

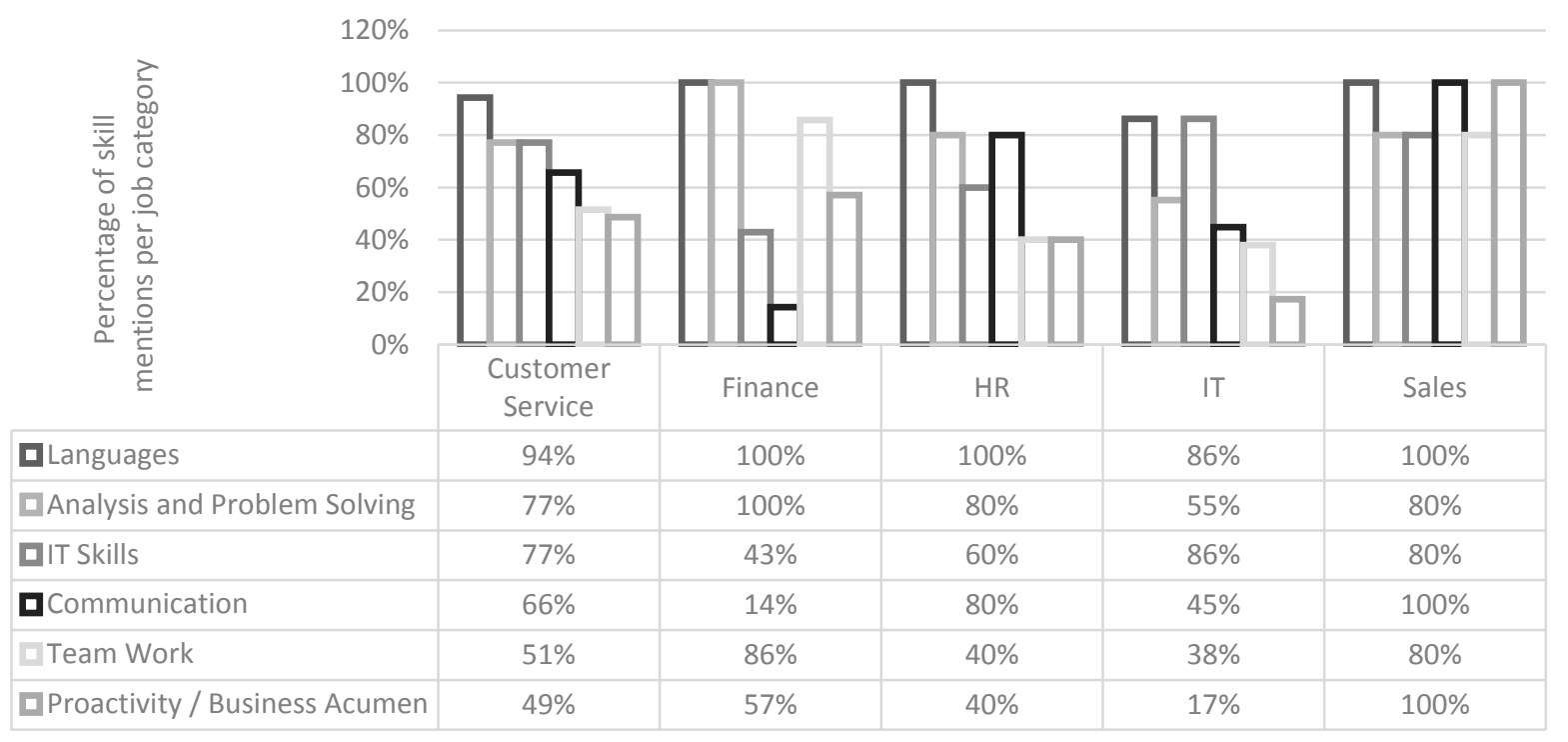

Figure 4. Percentage of skill mentions across job categories

Source: Authors' own research results/contribution.

We can, therefore, confirm that irrespective of job category language skills and IT skills continue to be in high demand. However, analysis and problem solving had not been identified in previous report outcomes of the Romanian Outsourcing Industry such as the ABSL and KPMG (ABSL \& KPMG, 2016; ABSL \& KPMG, 2017). It is unexpected that the communication skills within the Finance job category demonstrated a low demand compared with the other job categories with only 14\%. Also, an unforeseen result is that ITrelated job descriptions did not demand much of proactivity and business acumen skills. 


\section{Conclusions}

The primary purpose of this article was to understand which skills are currently in demand by the outsourcing sector, with the aim to continually be competitive on a global level and to match with a digitalized world. Further, it intended to provide direction to the educational and governmental institutions by giving insight on the requirements of a growing business sector in Romania regarding the skills needed.

The findings of the research show that irrespective of job categories analyzed the Romanian outsourcing sector is following the movement of the Industrial Revolution 4.0 regarding employability skills. The fourth industrial revolution is characterized by the combination of technologies that are disrupting the lines between the physical, digital, and biological spheres (Schwab, 2015). It implies the conversion of analog information into digital. The digitalization of things has a significant impact on the workforce at various levels such as rationalization, knowledge, performance, efficiency or skill set.

The results of this study show a high demand for language skills irrespective of job category which is explainable due to the nature of the business which offshores business services to reduce costs. However, the need for language skills might change in time with the technological advancements that instant translation systems allow. To understand the extent to which language skills will continue to be demanded and might need an effort to be increased within the employable population implies further research.

Concerning IT Skills, there is mainly a high demand for Office Suits which is considered as one of the leading communication tools in our globalized economy. The authors consider that transferring skills in this respect could be encouraged amongst all students through universities as it does not imply a too high level of technicality. Already today many office suits providers like Microsoft have special prices for students or have particular agreements with universities to provide their software. However, students would need to be encouraged to use these tools more with exercises by the education system.

The increased demand for more technical abilities within Development Environment, Network Protocols and Programming is more challenging when trying to build up a talent pipeline with this skills as these are not "universal" abilities that are very popular and need a more extended period of technical training. A joint effort is needed by different stakeholders to promote this ability amongst talent to be able to generate a critical mass of talent.

The World Economic Forum Report on the Future of Jobs (2016) anticipates that the computer and mathematical job family relating to data analysts, software and application developers will have high growth rates not only for the IT and Communication sectors but also to a wide variety of other sectors including the Professional Services Sector. With this analysis of the Romanian Outsourcing Industry, we can confirm this trend as well as the trend for the higher demand for analysis and problem-solving skills due to digitization.

The latter trend can be derived from the big mass of data that can be collected through automation and from the requirement to derive conclusions to be able to add value to the services provided to customers.

This paper has given an initial direction for further research within the skillset demand of the Romanian outsourcing industry. It needs to be deepened how much technical skills in specific services such as Human Resources, Finance, and Accounting, Procurement are needed by the industry based on the low number of specific skill mentions on the job descriptions also across job categories. Further research should focus on how the 
business sector together with the governmental and educational institutions can collaborate to comply with the skillset in demand.

Although job descriptions are indicators to provide an objective measure of business requirements, these do not describe the level of competence needed. This could be understood as a shortage of the outcome. Therefore, it is crucial that future employees, employers, and universities understand the precise level of skill attributes to be able to cope with the skills in demand.

\section{References}

ABSL \& KPMG (2016), “Outsourcing Industry Report”, available at https://www.absl.ro/press-room/\#reports, (accessed February 27, 2018).

ABSL \& KPMG (2017), "Outsourcing Industry Report", available at https://www.absl.ro/press-room/\#reports, (accessed February 27, 2018).

Andrews, J., and Higson, H. (2008), “Graduate Employability, 'Soft Skills' Versus 'Hard' Business Knowledge, A European Study”, Higher Education in Europe, Vol. 33, No. 4, pp. 411-422, doi: 10.1080/03797720802522627.

AT Kearney (2016), "Global Services Location Index Report", available at https://www.atkearney.com/documents/10192/7094247/On+the+Eve+of+Disrupt ion.pdf /49fa89fa-7677-4ab8-8854-5003af40fc8e, (accessed February 27, 2018).

Asonitou, S. (2015), "Employability Skills in Higher Education and the Case of Greece", Procedia - Social and Behavioral Sciences 175, pp. 283-290.

Barrett, S., Burgess, J., and Campbell, I. (2005), “The Australian Labour Market” 2004, Journal of Industrial Relations, Vol. 47, No. 2, pp. 133-150.

Basavaraj, and Anjaneya, B. (2014), "Developing Skills to Improve Employability in IT Industry - A Study of NASSCOM and BPO" In Acme Intellects International Journal of Research in Management, Social Sciences \& Technology International conference On Empowering employability in Business Education on 6th May 2014, Channagiri, India, pp. $1-8$, available at https://www.acmeintellects.org/images/AIIJRMSST/Conferences/06052014/22B1.pdf (accessed February 28, 2018).

Belfiore, M.E., Defoe, T.A., Folinsbee, S., Hunter, J., and Jackson, N.S. (2004), "Reading Work: Literacies in the New Workplace", Hillsdale, NJ: Lawrence Erlbaum.

Blalock, H.M. (1979), "Social Statistics”, New York: McGraw-Hill

Benett, R. (2002), “Employers' Demands for Personal Transferable Skills in Graduates: a content analysis of 1000 job advertisements and an associated empirical study", Journal of Vocational Education and Training, Vol. 54, No. 4, pp. 457-476, doi: 10.1080/13636820200200209.

Boscor, D., and Baltescu C. (2014), "Romanias Competitive Advantage on the Global Outsourcing Market", Bulleting of the Transilvanian University of Brasov, Vol.7 (56), No. 1, pp. 149-154.

Bridgstock, R. (2009), “The graduate attributes we've overlooked: enhancing graduate employability through career management skills", Higher Education Research \& Development, Vol. 28, No. 1, pp. 31-44, doi: 10.1080/07294360802444347.

Britannica (2017), "Operating System", available at https://www.britannica.com/technology/operating-system, (accessed February 27, 2018). 
Burning Glass Technologies (2015), "The Human Factor, the hard time employers have finding soft skills", available at http://burning-glass.com/wpcontent/uploads/Human_Factor_Baseline_Skills_FINAL.pdf (accessed February 27, 2018).

CBRE Research (2015), "The Real Estate of Outsourcing in Romania”, CBRE REAL ESTATE CONSULTANCY SRL, available at http://www.secundatv.ro/base/media/2015/11/CBRE_The-Real-Estate-ofOutsourcing-in-Romania_Summary-1.pdf, (accessed February 27, 2018).

Colliers International (2017), "2017 Romania H1 Real Estate Trends", available at https://www.absl.ro/press-room/\#reports, (accessed February 27, 2018).

Collins English Dictionary - Complete and Unabridged, 12th Edition (2014), "Development environment", available

at https://www.thefreedictionary.com/Development+environment, (accessed February 27, 2018).

Dearing, R. (1997), "Higher Education in the Learning Society", Report of the National Committee of Inquiry into Higher Education, London: HMSO.

Deloitte (2017), "Global Shared Services - 2017 Survey Report", available at https://www2.deloitte.com/content/dam/Deloitte/us/Documents/process-andoperations/us-global-shared-services-report.pdf, (accessed February 27, 2018).

EC (2010), "An Agenda for new skills and jobs: A European contribution towards full employment", COM (2010) 682 final, Brussels: European Commission, available at http://eur-lex.europa.eu/resource.html?uri=cellar:776df18f-542f-48b8-9627-

88aac6d3ede0.0003.03/DOC_1\&format=PDF, (accessed February 27, 2018).

European Commission/EACEA/Eurydice (2014), "Modernisation of Higher Education in Europe: Access, Retention, and Employability", Eurydice Report, Luxembourg: Publications Office of the European Union. doi:10.2797/72146.

ESECT (2017), "Employability", available at http://www.qualityresearchinternational.com/esecttools/definition.php, (accessed February 27, 2018).

Foerster-Pastor, U.S., and Golowko, N. (2017), "Employability skills for the Romanian Outsourcing Industry", in: 2017 The 11th International Conference on business excellence - Strategy, Complexity, and Energy in changing times, March 30-31, Bucharest, Romania, pp. 1068-1080, doi: https://doi.org/10.1515/picbe-2017-0110.

Gerholz, K.-H., and Sloane, P.F.E. (2011), "Lernfelder als universitäres Curriculum? - Eine hochschuldidaktische Adaption", bwp@ Berufs- und Wirtschaftspädagogik 20, pp. 124, available at http://www.bwpat.de/ausgabe20/gerholz_sloane_ bwpat20.pdf, (accessed February 27, 2018).

Golowko, N., Just, V., Bartels, A., and Scheiblich, M. and Studeny, M. (2017), “Approach for Measuring Sustainable Employability - a Concept for Academic Education", in: Proceedings of 11th annual International Technology, Education and Development Conference Valencia INTED, March 6-8, Valencia, Spain, pp. 2094-2104, doi: 10.21125/inted.2017.

Harvey, L., Locke, W., and Morey, A. (2002), "Enhancing Employability, Recognising Diversity: Making Links between Higher Education and the World of Work", London: Universities UK. 
Hillage, J., and Pollard, E. (1998), "Employability: Developing a Framework for Policy Analysis", DfEE Research Report RR85, November 1998, Department for Education and Employment: London.

Investopedia

(2017a),

"Outsourcing",

available

at

https://www.investopedia.com/terms/o/outsourcing.asp\#ixzz57ZavWe1X, (accessed February 27, 2018).

Investopedia (2017b), "Enterprise Resource Planning - ERP", available at https://www.investopedia.com/terms/e/erp.asp (accessed February 27, 2018).

Ismail, S., and Mohammed, D.S. (2015), "Employability Skills in TVET Curriculum in Nigeria Federal Universities of Technology", in: Procedia - Social and Behavioral Sciences 204, pp. 73-80, doi: 10.1016/j.sbspro.2015.08.111.

Kaplan, A.M., and Haenlein, M. (2009), "The fairyland of second life: Virtual social worlds and how to use them", Business Horizons, Vol. 52, No. 6, pp. 563-572.

Knight, P.T., and Yorke, M. (2003), "Employability and good Learning in Higher Education", Teaching in Higher Education Vol. 8, No. 1, pp. 3-16, doi: $10.1080 / 1356251032000052294$.

Knight, P.T., and Yorke, M. (2004), "Employability, Judging and Communicating Achievements", York: LTSN.

Kraus, K. (2007), "Beruflichkeit, Employability und Kompetenz. Konzepte erwerbspädagogischer Pädagogik in der Diskussion”, in: Dehnbostel, P., Elsholz, U., Gillen, J. (eds.): Kompetenzerwerb in der Arbeit, Berlin: Edition Sigma, pp. 235-248.

Lacity, M., and Willocks, L. (2016), "A new approach to automating services", in: MIT Sloan Management Review, Vol. 58, No. 1, pp. 40-49.

Marius C., Mare C., Moldovan C., China A., Farole T., Vințan A., Park J., Garrett K.P., and Ionescu-Heroiu, M. (2017), "Magnet Cities: Migration and Commuting in Romania" Washington, DC: World Bank.

Marks, M. (2015), "Rumänien mit starker Outsourcing Branche”, Germany Trade and Invest available at http://www.gtai.de/GTAI/Navigation/DE/Trade/Maerkte/suche,t=rumaenienmitstarker-outsourcingbranche,did=1360268.html, (accessed February 27, 2018).

Mayring, P. (2014), "Qualitative content analysis: theoretical foundation, basic procedures, and software solution", available at https://www.ssoar.info/ssoar/handle/document/39517; (accessed February 27, 2018).

Niethammer, C., Koglin-Hess, I., Digel, S., and Schrader, J. (2014), „Herausforderung Curriculumentwicklung. Ein konzeptioneller Ansatz zur Professionalisierung", in: Zeitschrift für Hochschulentwicklung, pp. 27-40.

Oria, B. (2012), "Enhancing higher education students' employability: A Spanish case study", in: International Journal of Technology Management \& Sustainable Development, Vol., 11, No. 3, pp. 217-230, doi: 10.1386/tmsd.11.3.217_1.

Oxford Dictionary Online (2017), "Skill", available at https://en.oxforddictionaries.com/definition/skill, (accessed February 19, 2018).

Patag K.J. (2017), "Demand for Digital Ready Workers grows as BPO evolve - LinkedIn", Busines World Online, available at http://bworldonline.com/content.php?section=Labor\&title=demand-for-digital- 
ready-workers-grows-as-bpo\&8217s-evolve----linkedin\&id=145792, ， (accessed February 27, 2018).

Pietro, G.D., and Cutillo, A. (2006), "University quality and labour market outcomes in Italy", in: Labour, Vol. 20, No. 1, pp. 37-62.

Pratt, M.K (2015), "10 Hottest Tech Skills for 2016", Computerworld, available at https://www.computerworld.com/article/3012033/it-skills-training/10-hottesttech-skills-for-2016.html, (accessed February 27, 2018).

Preisendörfer, P. (2015), “Organisationssoziologie: Grundlagen, Theorien und Problemstellungen”, Springer.

PwC (2014), “Talent - new challenges ahead”, 17 Annual Global CEO Survey. (2014, June 6), available at http://read.pwc.com/i/243985-pwcs-17th-annual-global-ceo-survey (accessed November 30, 2017)

Schwab, K. (2015), "The Fourth Industrial Revolution - what It Means and How to Respond", available at https://www.foreignaffairs.com/articles/2015-12-12/forthindustrial-revolution, (accessed February 20, 2018).

Shiel, C., Williams, A., and Mann, S. (2005), "Global Perspectives and Sustainable Development in the Curriculum: Enhanced Employability, More Thoughtful Society?", in: Newland, B., Norman, K., and Johnson, M. (eds.). Enhancing graduate employability, the Roles of learning, Teaching, Research and Knowledge Transfer. Proceedings of the Bournemouth University Learning and Teaching Conference, pp. 63-77, Poole: Bournemouth University.

Stiwne, E.E., and Alves, M.G. (2010), "Higher Education and Employability of Graduates, Will Bologna Make a Difference?”, in: European Educational Research Journal, Vol. 9, No. 1, pp. 32-44, doi: 10.2304/eerj.2010.9.1.32.

Technopedia (2017a), "Service available at https://www.techopedia.com/definition/30494/service-desk, (accessed February $27,2018)$.

Technopedia (2017b), "Programming Language", available at https://www.techopedia.com/definition/24815/programming-language, (accessed February 27, 2018).

Technopedia (2017c), "Network Protocols", available at https://www.techopedia.com/definition/12938/network-protocols, (accessed February 27, 2018).

Wissenschaftsrat (2000), "Empfehlungen zur Einführung neuer Studienstrukturen und abschlüsse (Bakkalaureus/Bachelor - Magister/Master) in Deutschland". Drs. 4418/00; available at http://www.wissenschaftsrat.de/download/archiv /4418-00.pdf, (accessed February 27, 2018).

World Economic Forum (2016), "Global Challenge Insight Report -The Future of Jobs Employment, Skills and Workforce Strategy for the Fourth Industrial Revolution", available at http://www3.weforum.org/docs/WEF_Future_of_Jobs.pdf, (accessed February 27, 2018).

Yourdictionary, "Application Suite", available at http://www.yourdictionary.com/application-suite\#computer, (accessed February $27,2018)$. 